\title{
IMPLEMENTASI SYSTEM INFORMASI: DARI RESISTENSI, REKAYASA BISNIS, HINGGA PENCIPTAAN KEMAKMURAN
}

\begin{abstract}
Yazid ${ }^{*}$
Abstract

It is hoped that by using information system (IS) or information technology (IT) business world will be able to take more and more benefits, and customers could be more satisfied. IT is not surprising, therefore, if the decision on information system investment becomes an integral part of the overall organization's strategies. Yet, the success of IS development much depends on several factors such as the ability of management to identify the sources of and overcome change resistance. Satisfying customers is very promising effort: increase cash flow and profit. Yet, the result, mainly, depends on the management or researchers' perception about satisfaction score, the costs should be incurred, and the management understanding about the concept and tools of IS. This paper will discuss about change resistance and alternative ways to overcome the problem, satisfaction trap, the important of cost reduction in IS implementation, and concept and tool to be understood by managers, especially the managers of service organizations.
\end{abstract}

Keywords : change resistence, information system, customer satisfaction

\section{PENDAHULUAN}

Meningkatnya perkembangan komputer dan teknologi informasi telah memberikan dampak yang cukup besar terhadap tempat kerja baru dan para manajernya. Sistem informasi diyakini banyak pihak memberi kontribusi terhadap kebutuhan untuk membangun keunggulan kompetitif melalui biaya yang rendah, kualitas yang lebih baik, dan peningkatan pelayanan kepada konsumen. Informasi merupakan fondasi pengawasan manajerial. Bila efektivitas pengawasan menjadi prioritas, maka setiap sistem pengawasan harus mengkomunikasikan informasi yang benar pada waktu yang benar dan kepada orang yang benar. Dengan kata lain, efektivitas kerja para manajer memerlukan dukungan dari sistem dan teknologi informasi yang memadai. Sejumlah buku teks mengenai manajemen menyebutkan bahwa efektivitas para manajer itu bisa diukur dari cash flow dan profit yang diperoleh organisasi yang berada di bawah kepemimpinan mereka. Bagi Drucker (1995) cash flow dan profit saja belum cukup. Sebab menurut dia, pemanfaatan sistem/teknologi informasi harus juga mampu menciptakan kemakmuran ekonomi secara makro.

Suatu sistem informasi (SI) mencakup kegiatan pengumpulan, pengorganisasian, dan pendistribusian data sedemikian rupa sehingga data tersebut menjadi informasi yang bermakna bagi pengambilan keputusan (manajerial). Sistem informasi yang baik sangat memfasilitasi setiap fungsi

Staf Pengajar pada Fakultas Ekonomi Universitas Islam Indonesia, Yogyakarta. 
manajemen, namun sistem ini akan memberi manfaat yang sangat besar khususnya bila dilibatkan dalam perencanaan dan pengawasan (Schermerhorn, 1996). Sementara teknologi informasi (TI) mencakup bukan hanya teknologi komputer (hardware dan software) untuk memproses dan menyimpan informasi, tetapi juga teknologi komunikasi untuk mengirimkan (transmitting) informasi ke berbagai bagian organisasi yang membutuhkannya untuk kepentingan pengambilan keputusan (Martin, et. al., 1999). Dari sejumlah buku teks tentang sistem informasi, pengertian SI diterima sebagai memiliki cakupan yang lebih luas daripada dan TI, dimana TI hanya merupakan bagian atau salah satu subsistem dari SI.

Ekonomi masa datang, termasuk di dalamnya persaingan, akan berada dalam zaman informasi (Tapscot, 1995; Martin, et. al., 1999; Schermerhorn, 1997). Kelangsungan hidup organisasi bisnis dan pemenangan persaingannya amat ditentukan oleh kelengkapan dan akurasi informasi yang dimiliki oleh organisasi Itu sendiri. Namun demikian, penerapan SI sering menjumpai sejumlah kendala, termasuk diantaranya kendala resistensi yang bukan saja berasal dari lingkungan internal organisasi, akan tetapi bisa juga berasal lingkungan eksternal organisasi: konsumen. Resistensi konsumen memiliki alasan yang cukup rasional, dapat mempengaruhi perilaku beli mereka, dan karenanya perlu mendapat perhatian serius dari para manajer.

Kendala lain yang tidak kalah pentingnya adalah terbatasnya wawasan para manajer berkenaan dengan manfaat dari implementasi TI. Mayoritas manajer, seperti tercermian dalam keputusan-keputusan mereka, hanya menekankan manfaat bagi organisasi mereka an sich (mikro). Wawasan semacam ini, barang tentu, memiliki resiko yang cukup besar. Sebab, sangat mungkin terjadi, karena terlalu fokusnya perhatian para manajer dalam memaksimalkan perolehan mereka, mereka sering keliru dalam menyajikan value, melalui barang/jasa yang mereka tawarkan, kepada konsumen. Karena konsumen memiliki pilihan yang sangat luas, sltuasi semacam ini diyakini cukup menjadi pemicu bagi konsumen untuk beralih ke barang/jasa yang ditawarkan pesaing yang memenuhi value yang diharapkannya. Paper ini akan mengajukan beberapa hal dengan maksud agar para manajer tidak terjebak dalam pemikiran atau tindakan yang justru akan menjauhkan konsumen dari mereka.

\section{SI DAN RESISTENSI}

Pengembangan sistem informasi memerlukan investasi yang cukup besar, baik untuk membeli peralatan pendukungnya, maupun biaya selama peralihan dari sistem manual ke sistem yang berbasis komputer (computerized), serta biaya untuk perubahan perilaku personel dan organisasional. Oleh karena Itu, keberhasilan pengembangan sistem tersebut tidak hanya bergantung kepada perubahan dan/atau majunya teknologi yang digunakan. Ada sejumlah faktor lain yang mempengaruhi keberhasilan sistem dimaksud. Setianingsih (1998) mengatakan bahwa faktor-faktor yang mempengaruhi keberhasilan perubahan sistem informasi, antara lain, adalah partisipasi pemakai, keterlibatan pemakai, 
komunikasi pengguna-pengembang, dukungan manajemen puncak, pelatihan, ketersediaan informasi berkenaan dengan perubahan sistem pada tahap awal, dan kualitas pemakainya.

Pengambangan SI seringkali memerlukan perubahan organisasional yang cukup besar atau mendasar, yang mencakup hingga ke perubahan paradigma bisnis. Proses-proses manual banyak yang digantikan dengan caracara yang lebih maju (computer-based). Fakta ini membawa konsekuensi yang tidak ringan bagi para karyawan. Maka resistensipun menjadi masalah yang tidak bisa dihindarkan oleh kebanyakan perusahaan. Bagaimana perusahaan mengatasi masalah ini?

Banyak para ahli menyarankan bahwa penggunaan komputer di dalam proses bisnis, tidak dimaksudkan untuk menggantikan para karyawan, akan tetapi justru menjadi alat bantu bagi para karyawan sehingga mereka bisa lebih produktif lagi. Pendapat ini tentu lebih mudah diucapkan daripada dilaksanakan. Sebab pernyataan mereka itu menuntut ditingkatkannya kreativitas dan kemampuan inovasi perusahaan. Pemanfaatan informasi pun tidak luput dari tuntutan semacam ini.

Sistem informasi dan teknologi informasi yang dipakai oleh sebuah perusahaan hendaknya tidak hanya dimaksudkan untuk kepentingan perubahan proses untuk tujuan efisiensi di setiap tahapan proses produksi. Akan tetapi, labih jauh daripada itu, yaitu untuk menemukan model bisnis baru yang lebih menjanjikan dilihat dari kemampuannya memberi lebih banyak value kepada konsumen.

\section{SUMBER-SUMBER RESISTENSI}

Resistensi merupakan masalah inheren dari penerapan SI yang baru. Kotter (1995), menyatakan bahwa perubahan besar tidak akan terjadi, kecuali bila perubahan Itu mendapat dukungan aktif dari organisasi. Karena perubahan Itu memerlukan "biaya" yang besar, maka wajar bila ada organisasi yang menghindari atau tidak mau sama sekali melakukan perubahan (Quinn, 1996). Pendapat ini diperkuat oleh adanya kenyataan bahwa struktur-struktur dan proses-proses di dalam organisasi itu akan mendorong keseimbangan, bukannya perubahan. Di satu sisi, kenyataan ini menurut Robbins (1994), adalah positif, sebab bila dalam suatu organisasi tidak ada resistensi terhadap perubahan, karakteristik perilaku organisasional akan menjadi random, tidak bisa diperkirakan. Disini, resistensi berfungsi mempertahankan derajat stabilitas dan kemampu-prakiraan perilaku. Disamping itu, resistensi terhadap perubahan dapat juga menjadi salah satu sumber konflik fungsional (konflik yang positif). Contoh, resistensi terhadap perubahan akibat adanya reorganisasi atau perubahan dalam sistem informasi dapat memunculkan perdebatan berkenaan dengan masalah perawatan kesehatan pasien yang disttimulasi oleh adanya value-value atau ide-ide tentang perawatan kesehatan yang baru atau hasil dari keputusan yang lebih baik. Namun demikian, resistensi juga mengandung sisi gelap, yaitu berkenaan dengan potensinya dalam menghalangi adaptasi dan perkembangan organisasi atau bisnis. 
Robbins (1994), mengatakan bahwa sumber resistensi itu ada dua, yaitu sumber individual dan sumber organisasional. Sumber-sumber individual antara lain berupa keengganan merubah kebiasaan, terancamnya rasa aman, faktor-faktor ekonomis, ketakutan tentang sesuatu yang tidak diketahui, dan proses informasi selektif. Sementara itu, resistensi organisasional antara lain disebabkan oleh adanya inertia structural, erbatasnya fokus terhadap perubahan inertia kelompok, ancaman berkenaan dengan keahlian, ancaman terhadap kemapanan hubungan kekuasaan, dan ancaman terhadap kemapanan alokasi sumber-sumber.

Karena alasan-alasan seperti itu, Kotter (1995), menyarankan para manajer untuk memperhatikan hal-hal di luar dari dukungan manajer. Dalam transformasi yang berhasil, pinpinan perusahaan atau presiden perusahaan atau wakil direktur umum, ditambah dengan sejumlah orang lain sebanyak 5 50 orang (banyaknya orang yang dilibatkan dalam proses perubahan itu bergantung kepada besar-kecilnya ukuran perusahaan, secara umum, makin besar ukurannya makin banyak orang yang perlu dilibatkan), untuk duduk bersama membicarakan atau mengembangkan komitmen bersama untuk mencapai unjuk-kerja yang terbaik melalui perbaikan sistem informasi. Masih menurut Kotter (1995), berdasarkan pengalamannya, ia belum pernah melihat para manajer melibatkan para eksekutif senior karena sejumlah orang tidak menyetujui perubahan tersebut, paling tidak pada tahap-tahap awalnya. Menurut pengalamannya, pada kebanyakan kasus penerapan infomrasi teknologi baru yang berhasil, koalisi tersebut selalu sangat kuat - dalam terminologi jabatan, informasi dan keahlian, reputasi dan hubungan.

Kedua sumber resistesi tersebut cenderung dialamatkan kepada individu dalam organisasi dan kepada organisasi itu sendiri. Pada kenyataannya, konsumen mungkin dapat pula menjadi sumber resistensi. Sebuah riset yang dilakukan didalam suatu industri yang bergerak di bidang perawatan kesehatan mengungkapkan bahwa $82 \%$ dari konsumennya tidak menyukai customer-interface otomatis yang diusulkan perusahaan (Jones, 1996). Bitner (1996) menyatakan bahwa perbaikan kualitas (jasa) harus mencerminkan kebutuhan konsumen, tetapi sayangnya para konsumen tidak selalu mengetahui apa yang mereka inginkan di masa datang, khususnya ketika ketika melibatkan faktor teknologi (informasi). Namun demikian, Bitner percaya bahwa akan lebih baik bila para manajer mengetahui dengan jelas tentang persepsi konsumen mereka berkenaan dengan kualitas jasa yang menentukan bagaimana sistem (informasi) itu di-design dan diimplementasikan. Akan jauh lebih baik lagi bila perhatian terhadap persepsi dan kebutuhan konsumen dan kemudian digabungkan dengan pertimbangan standar sistem operasi mana yang akan dipakai, sehingga implementasinya akan memberi benefit maksimum kepada semua pihak. Ini semua demikian, sebab para manajer harus mampu menjawab dengan baik pertanyaan berikut ini: Akankah sistem baru benarbenar memnuhi kebutuhan-kebutuhan para konsumen?

Partisipasi dan keterlibatan para pengguna dan konsumen dalam perencanaan dan pengembangan $\mathrm{Sl}$, komunikasi umpan-balik antara pengguna dan pengembang, dukungan manajemen puncak, pelatihan sebelum dan 
sesudah tahap implementasi sistem, ketersediaan sejak awal informasi tentang perubahan SI dan kualitas pengguna sistem informasi adalah - menurut temuan sejumlah riset - merupakan faktor-faktor yang dapat mempengaruhi kepuasan pengguna. Faktor-faktor ini harus dilibatkan didalam pengembangan SI, sehingga SI yang dikembangkan itu dapat memperbaiki kontrol internal perusahaan, meminimumkan biaya-biaya relevan dan menyediakan informasi yang akurat.

\section{BILA KONSUMEN MENOLAK TI YANG BARU}

Para manajer mungkin menemukan solusi yang baik bila mereka memahami benar penolakan konsumen. Thomas O. John (1996) menemukan lima kemungkinan yang membuat konsumen enggan menerima TI yang baru.

1. Konsumen, secara tradisional, kesulitan dalam menemukan/ mengidentifikasi benefit yang akan diperoleh dari teknologi, khsusnya bila teknologi itu menggantikan interaksi antar manusia. Dari riset yang telah disebutkan di atas, $71 \%$ dari $82 \%$ konsumen yang telah menyatakan bahwa mereka tidak akan menyukai sistem customer-interface otomatis yang diusulkan, dengan segera memilih untuk menggunakan alat yang sebelumnya mereka tolak. Inilah saat yang tepat untuk mengabaikan "suara" konsumen. Konsumen tidak selamanya benar. Karena itu keputusan untuk menggunakan TI yang baru perlu dipertahankan.

2. Apabila konsumen diberi pilihan antara kecepatan dan akurasi di satu sisi, dan kenyamanan dan perhatian di sisi yang lain, para konsumen akan memberi respon yang tidak sama. Bagi mereka yang berasal dari daerah yang padat penduduknya, akan lebih memilih kecepatan dan akurasi daripada kenyamanan dan perhatian. Interaksi-interaksi berdasarkan perhatian dengan orang lain dapat memiliki efek positif yang sangat besar dalam pengalaman jasa, tetapi tidak dimaksudkan untuk mengganti ketepatan dan keandalan pengalaman jasa. Akan selalu ada orang yang memilih interaksi antar manusia daripada kenyamanan, khususnya orang yang pernah mengalami servis yang jelek (menyakitkan) atau lingkungan yang tidak ramah. Namun, secara keseluruhan, sistem reservasi berbasis komputer akan mengurangi banyak prosedur dan personel (more streamlined), lebih bisa dipercaya, tidak membuat stress, dan dalam banyak cara merupakan pengalaman yang lebih bisa dinikmati oleh konsumen. Karena itu, memiliki pemahaman yang baik tentang latar belakang kultural, sosial, serta persepsi konsumen, diyakini akan memberikan pertimbangan yang lebih luas berkenaan dengan benefit/value TI/SI yang akan ditawarkan kepada konsumen.

3. Wujud dari upaya perusahaan untuk memuaskan konsumen, sebenarnya, mungkin belum memberikan/menunjukkan kemampuan terbaiknya. Dari riset yang dilakukan Moulter, 86\% konsumen perusahaan memilih baik angka empat atau lima pada skala yang terdiri dari lima-poin. Dari riset itu, disimpulkan bahwa hanya konsumen yang memilih angka lima yang 
akhirnya benar-benar menjadi konsumen yang setia (membeli lagi). Ini berarti bahwa jumlah konsumen yang tidak bisa dipuaskan ternyata cukup signifikan, transaksi mereka dengan perusahaan berada dalam resiko. Karena itu, ini adalah pertanda peringatan yang cukup serius bagi perusahaan. Perusahaan harus membangun kembali keunggulan kompetitifnya sesegera mungkin, baik melalui stratgei kembali ke bisnis inti maupun kembali kepada kemampuan inti

4. Perubahan ke infrastruktur yang baru pada sistem informasi akan memberi sejumlah benefit kepada karyawan, dan tanpa pemotongan jumlah karyawan yang berarti, perubahan itu akan membuat perusahaan justru akan lebih mampu untuk lebih memfokuskan diri kepada aktivitasaktivitas yang lebih memberikan value kepada para konsumen. Sistem tersebut, selanjutnya, akan menyediakan informasi yang akurat tentang level-level proses penyajian jasa - termasuk waktu tunggu aktual. Pengukuran yang lebih baik tentang pengalaman konsumen dapat memberikan benefit/value yang mereka harapkan.

5. Sering terjadi bahwa apa yang tampaknya sebuah perubahan besar, sebenarnya tidaklah demikian - atau paling tidak - tidak seharusnya demikian. Fungsi dari bagian resepsionis mencerminkan sisa dari keseluruhan aktivitas yang dilakukan (teknologi yang dipakai) perusahaan. Jadi, sebenarnya komitmen bagian resepsionis terhadap teknologi baru disini memperlihatkan komitmen bagian resepsionis terhadap teknologi secara umum. Momentum semacam ini sebaiknya terus dipelihara, dengan cara meningkatkan pelatihan karyawan dan terus mmemelihara motivasi mereka dengan dibantu reward dan hukuman yang tepat.

\section{PERANGKAP KEPUASAN}

Pembahasan di atas didasarkan kepada penerapan SI/TI yang berorientasi kepada konsumen. Banyak ahli berpendapat bahwa kemampuan memuaskan konsumen merupakan senjata ampuh dalam membangun dan mempertahankan keunggulan kompetitif. Akan tetapi hendaknya para pebisnis berhati-hati dengan pernyataan ini, sebab keyakinan semacam ini memiliki kemungkinan justru yang menjadi sebab kehancuran bisnis.

Sebelum paper ini mendiskusikan lebih jauh perangkap kepuasan, ada baiknya jika paper ini menyajikan contoh ilustratif berikut ini. Dari contoh ini pembaca diharapkan akan memperoleh gambaran mengenai upaya organisasi memuaskan konsumennya, namun yang diperoleh konsumen justru hal yang mengecewakan. Pernahkah anda berada di sebuah hotel dimana sikap dari manajemen dan stafnya tidak seperti yang anda lihat, seperti membiarkan para tamu memenuhi ruang lobby, para tamu mengotori kamar mereka sendiri, para sebentar-sebentar menelepon meminta servis kamar; padahal para karyawan hotel itu sebenarnya mampu melakukan pekerjaanpekerjaan mereka dengan jauh lebih baik dari pada saat itu? Pernahkah anda, ketika berkunjung ke salah satu klinik kesehatan, nama anda sudah dipanggil, diminta untuk masuk ke kamar periksa, lalu diminta membuka baju, dan 
terbengong-bengong selama 20 menit menunggu dokter sementara pembantu dokter disitu sudah mengatakan: "Sabar sedikit ya, sebentar dokter juga datang." Atau sederet pengalaman pahit lainnya.

Bila jawabannya "ya" untuk salah satu dari dua contoh situasi di atas, maka anda telah benar-benar mengetahui sejumlag cara-cara yang membuat konsumen frustrasi, padahal maksudnya adalah membuat konsumen merasa puas. Secara singkat dapat dikatakan maksudnya memuaskan (komunikatif dengan) konsumen, apadaya hasilnya justru membuat konsumen frustrasi. Meski demikian, jangan terburu-buru menyalahkan karyawan. Situasi semacam ini mungkin memiliki akar masalah lebih dalam daripada sekedar sikap petugas di meja depan yang tidak seharusnya demikian. Seperti tut piano yang menunggu ditekan agar mengeluarkan bunyi tertentu, merupakan contoh terbaik untuk menggambarkan situasi semacam ini, yaitu para karyawan hanya berusaha menjalankan atau mengikuti apa yang boss mereka inginkan/diktekan kepada mereka.

Sejumlah manajer bisa saja mengklaim bahwa situasi-situasi tersebut mencerminkan trade-off antara kepuasan konsumen berhadapan dengan keharusan mempertahankan produktivitas yang tinggi, sementara biaya semakin ditekan menjadi lebih rendah dan lebih rendah lagi (Lovelock, 1994). Para manajer tersebut berpendapat bahwa dalam pasar yang sangat kompetitif para konsumen akan pindah menjadi konsumen perusahaan lain bila biaya produksi (harga produk) mereka tidak ditekan dan ditekan lagi. Barang tentu keadaan ini akan mengakibatkan perusahaan tidak akan bisa memperoleh profit, karena biaya produksinya malah justru meningkat. Jika sudah seperti ini keadaannya, perusahaan tersebut tidak bisa melakukan investasi untuk keperluan masa depannya.

Dalam konteks seperti di atas, upaya memenangkan persaingan dengan menggunakan senjata efisiensi hanya mampu meyakinkan secara marjinal, sebab ada hal yang lebih buruk yang akan datang menjelang dibalik dari upaya penurunan biaya proses. Untuk mencapai efisiensi, banyak manajer memilih menggunakan standarisasi untuk semua proses-proses produksinya. Akan tetapi hasilnya justru diluar dari yang diharapkan, sebab banyak konsumen yang mengeluh bahwa perusahaan tidak responsif dan birokratis. Para konsumen, pada gilirannya, memiliki gambaran yang negatif berkenaan dengan fasilitas perusahaan (jasa) di dalam mana mereka berurusan dari satu bagian ke bagian yang lain untuk menyelesaikan sebuah transaski, antrian yang panjang, personel yang malas dalam melayani konsumen dan berkata "ini bukan pekerjaan saya" atau "saya tidak diperkenankan untuk melakukan hal seperti itu," lokasi dan jam layanan yang tidak nyaman, penggantian karyawan jasa dengan mesin (TI) yang kompleks yang, celakanya, harus dioperasikan konsumen sendiri (swalayan), dan sejumlah aturan dan/atau peraturan yang sesungguhnya tidak diperlukan.

Di sisi lain, seorang produsen bisa saja menawarkan produk yang menurut mereka menjanjikan akan lebih mampu memuaskan para konsumen. Banyak organisasi melakukan rekayasa proses dan prosedur pembuatan barang atau jasa mereka. Untuk jasa, rekayasa mencakup mencakup sejak 
dari pemesanan (reservasi) jasa, pelayanan selama di tempat jasa diproses, sampai ke checkout/pembayaran di kasir. Tiba-tiba segalanya menjadi lebih sederhana/mudah, dan, memang, semakin efisien. Tidak lama setelah itu si produsen berkehendak melakukan riset kepuasan konsumen. Misal, hasil dari riset yang dilakukan produsen itu sungguh menggembirakan produsen: para konsumen bisa dipuaskan, bahkan konsumen menyatakan sangat puas. Akan tetapi apa yang terjadi segera setelah hasil riset itu terungkap? Ternyata para konsumen yang kembali membeli produk si produsen hanya antara 30\% sampai dengan $40 \%$ dari $90 \%$ yang sebelumnya menyatakan puas (Reichield, 1996). Mengapa hal ini bisa terjadi? Menurut Reichield ada dua hal sangat penting yang mungkin diabaikan dalam riset itu, yaitu:

1. Banyak periset dan produsen menganggap bahwa skore kepuasan telah menjadi tujuan akhir dari riset itu sendiri. Mereka lupa bahwa skore itu tidak berarti apa-apa, kecuali bila kepuasan yang hendak mereka ukur itu diterjemahkan (diproses lebih lanjut) ke dalam tindakan pembelian dan profit. Didasari oleh asumsi yang salah itu para produsen sangat mungkin mendapat skore kepuasan konsumen yang keliru, karena berbagai alasan/kepentingan yang mendasarinya.

2. Banyak daftar pertanyaan dari riset tentang kepuasan disusun secara serampangan dan pembagiannya kepada responden dilakukan secara sembrono pula. Riset-riset tersebut akhirnya mengukur aktivitas-aktivitas konsumen yang keliru. Fakta menunjukkan bahwa skore kepuasan itu sangat mudah dimanipulasi. Sejumlah perusahaan yang khusus menawarkan jasa riset telah mendorong sejumlah organisasi (barang/jasa) untuk menginvestasikan waktu dan uang mereka untuk kegiatan yang tidak produktif.

Selanjutnya Reichield menyodorkan sejumlah kemungkinan yang mendasari kegagalan kegagalan peneltian tentang kepuasan konsumen:

1. Pada sejumlah organisasi, skore kepuasan yang baik dianggap merupakan goal yang lebih tinggi daripada profit dan memiliki efek yang lebih segera terhadap kompensasi. Oleh karena itu para karyawan secara alamiah mencari - meski harus dengan memanipulasi skore kepuasan cara termudah untuk "memperbaiki" skore kepuasan konsumen. Celakanya, bila reward didasarkan atas skore kepuasan dan tanpa mengkaitkannya dengan kesetiaan konsumen dan profit, hasilnya adalah perilaku yang kontra-produktif.

2. Riset sangat mungkin tidak bisa berjalan dengan baik karena tidak pernah memberi informasi yang para manajer cari untuk keperluan investasi yang akan memaksimumkan value konsumen, dan, pada gilirannya, cash flow. Keberhasilan pada tahap awal dari skore riset sering diperoleh dari penetapan goal yang terlalu mudah dicapai dan/atau merupakan target jangka pendek (a matter of picking low-hanging fruit). 
3. Kekurangn lainnya dari penelitian kepuasan adalah riset ini mengabaikan perbedaan yang penting diantara segmen-segmen pasar yang ada. Banyak perusahaan hanya memberi perhatian yang sedikit terhadap apa yang dikatakan (diharapkan) konsumen dan kurang usah dalam melacakl enelit catatan pembelian konsumen. Sebenarnya penelitian kepuasan itu sangat penting, karena hasilnya bisa mendorong perusahaan untuk mewujudkannya ke dalam investasi SI sehingga mampu memberikan value potensial tertinggi kepada konsumen. Bila riset ini dilakukan dengan menjaring konsumen secara lebih luas - tetapi dengan pendekatan yang benar secara statistik - riset tersebut akan mampu mengungkapkan siapa saja konsumen dan/atau segmen mana saja yang tidak menguntungkan bagi perusahaan. Contoh, seorang manajer cabang sebuah bank mendengar banyak keluhan tentang panjangnya antrian di depan teller, sementara sangat mungkin bahwa sebenarnya konsumen yang menguntungkan bank cabang itu adalah mereka yang bertransaksi melalui telepon, surat, atau ATM. Dalam situasi begini, melakukan investasi untuk memperbanyak teller (agar mampu memberi pelayanan yang lebih personal dan customized) mungkin bahkan akan menurunkan skore kepuasan. Sebab, secara pasti, walaupun cara ini akan menaikkan level pelayanan, cara itu akan menurunkan profit karena investasi untuk keperluan ini hanya akan berarti peningkatan ongkos pelayanan dimana para konsumen yang sangat menguntungkan perusahaan justru tidak memperdulikan ada-tidaknya peningkatan layanan teller tersebut.

Uraian di atas mengungkapkan sedikit dari sekian banyak pengalaman atau fakta berupa peraturan, prosedur dan informasi (skore kepuasan) yang mempengaruhi loyalitas konsumen. Uraian di atas menjelaskan kepada kita semua bahwa, ternyata, banyak juga perusahaan yang prioritas operasionalnya berakar pada kebiasaan mengubah fakta menjadi "product minuses" atau produk yang tidak kompetitif (Lovelock, 1994). Mengingat dampaknya yang begitu serius, para manajer harus sangat hati-hati dalam mempertimbangkan dampak (kepuasan konsumen dari) implementasi SI/TI yang baru.

\section{IMPLEMENTASI TIISI, KEMAKMURAN DAN PENGENDALIAN BIAYA}

Para manajer yang baik dituntut untuk tidak hanya memahami biaya operasi saja (Drucker, 1995). Agar berhasil di pasar yang terus meningkat menjadi semakin mengglobal, para manajer harus mampu memahami biaya dari rantai suatu ekonomi dan harus bekerja dengan rantai ekonomi lainnya untuk keperluan pengendalian biaya-biaya dan memaksimumkan perolehan (yield). Oleh karena itu manajer harus mau dan mampu, dari sejak sekarang, mengubah paradigma lamanya yang hanya memfokuskan kepada manfaat SI untuk keperluan pengendalian biaya-biaya internal perusahaan kepada biaya untuk keperluan keseluruhan proses ekonomi, dimana perusahaan terbesarpun hanya merupakan salah satu bagian rantainya saja.

Masalahnya ialah, perusahaan itu adalah suatu realita bagi pemegang saham, para kreditur, para karyawan, dan para petugas pajak, sementara itu, 
secara ekonomis, konsep perusahaan sebagai suatu mata rantai ekonomi masih merupakan fiksi belaka. Namun, sebenarnya konsep itu bisa dilacak. Perhatikan contoh berikut ini. Tiga puluh tahun yang lalu, Coca-Cola hanyalah sebuah franchisor bagi perusahaan pembotolan independen dari perusahaan yang memproses produk sebuah minuman ringan. Sekarang, perusahaan itu telah memiliki unit pembotolan sendiri yang sebagian besar beroperasi di Amerika. Namun, para penikmat Coke tidak bisa mengabaikan fakta-fakta tersebut ${ }^{1}$. Jadi, ternyata, apa yang menjadi persoalan di pasar adalah realitas ekonomi, biaya dari keseluruhan proses, tanpa memperdulikan siapa memiliki apa.

Karena itu, masih menurut Drucker (1995), produsen tidak memiliki pilihan lain kecuali bahwa SI perusahaan harus dimplementasikan dalam kerangka menciptakan kemakmuran, bukannya kontrol biaya. Tapscot (1996) mengatakan bahwa menambahkan ide-ide dalam suatu produk (kreativitas dan inovasi, pen.) akan menjadi sangat penting bagi penciptaan kemakmuran di dalam ekonomi baru di masa datang. Dengan demikian, menjadi jelas bahwa kreativitas dan inovasi akan memiliki peran yang semakin penting bagi keunggulan kompetitif perusahaan di masa datang.

Akan tetapi, agar kreativitas dan inovasi tersebut benar-benar membuat perusahaan sukses dimasa datang, Drucker menyarankan agar sebaiknya perusahaan perlu lebih dahulu memiliki empat set alat diagnostik (taktik), yang mencakup informasi dasar, informasi produktivitas, informasi kompetensi, dan informasi tentang alokasi sumber-sumber yang langka.

1. Informsi dasar. Alat diagnostik manajemen paling tua dan paling luas digunakan adalah proyeksi cash-flow dan liquiditas serta pengukuran standar seperti ratio antara penjualan dengan sediaan, piutang dagang, atau piutang total; kemampuan perolehan untuk membayar bungan hutang obligasi yang dikelurkan perusahaan. Proses-proses ini sama dengan cara dokter memeriksa (mengukur) kesehatan pasien: mengukur berat badan, tekanan darah, suhu badan, dan analisis urine. Bila hasil pengukuran itu menunjukkan pasien dalam keadaan normal, maka informasi ini tidak berbicara banyak, sebaliknya, bila hasil pengukuran Itu menunjukkan ada sesuatu yang tidak normal, maka itu berarti dokter tersebut perlu malakukan diagnosa lebih lanjut untuk menemukan penyakit pasien dan cara pengobatannya. Informasi semacam ini disebut informasi dasar.

2. Informasi produktivitas (dari sumber-sumber kunci). Pengukuran produktivitas pekerja (baik karyawan kerah putih maupun kerah biru), tidak akan memberi infomasi yang cukup tentang produktivitas. Yang perlu diukur para manajer adalah faktor produktivitas total. Produktivitas toal dapat diukur dengan analisis nilai tambah ekonomis (economic valueadded analysis atau EVA) yang didasarkan kepada sesuatu yang telah

${ }^{1}$ Dengan membotolkan sendiri minuman produksinya, Coke bisa menekan biaya, lau harganyapun menjadi lebih kompetitif. Selanjutnya, rantai biaya dan harga ini, pada gilirannya, menciptakan efek ekonomi secara makro, khususnya bagi masyarakat Amerika, berupa penciptaan lapangan kerja, devisa, dan sebagainya. 
lama dikenal baik bahwa profit, uang yang tersisa untuk membayar jasa ekuitas, bukanlah profit dalam pengertian yang dimaksud disini. Sebab, jika perusahaan hanya mampu memperoleh "profit" yang cukup untuk menutupi biaya operasi, ia belum bisa dikatakan melaba, kecuali bila profit yang diperoleh itu mampu membiayai seluruh biaya kapitalnya. Perusahaan masih dianggap rugi bila perolehannya masih lebih kecil daripada biaya untuk seluruh sumber-sumber yang dipakainya.

Dengan mengukur nilai tambah untuk semua biaya, termasuk biaya kapital, EVA mengukur produktivitas semua faktor produksi. Jadi, alat ini tidak menerangkan mengapa produk tertentu atau jasa tertentu tidak memberi nilai tambah dan apa yang menjadi penyebabnya. EVA hanya memperlihatkan produk, jasa, operasi, atau kegiatan mana yang memiliki nilai tinggi yang tidak seperti lazimnya.

Cara lain untuk memperoleh informasi produktivitas adalah melalui benchmarking. EVA dan benchmarking menerangkan tentang apa yang diperlukan untuk dan apakah perusahaan memerlukan tindakan yang dapat meningkatkan produktivtas total atau tidak. Secara bersama, EVA dan benchmarking merupakan alat diagnostik untuk mengukur faktor produktivitas total dan bagaimana mengelolanya.

3. linformasi kompetensi. Kepemimpinan, menurut C.K. Prahalad dan Garry Hamel (1990) tercermin dari kemampuan seseorang untuk melakukan sesuatu yang orang lain tidak bisa melakukannya atau sulit melakukannya meskipun dengan hasil yang jelek. Kemampuan ini mencerminkan kemampuan inti (core competencies) yang menggabungkan pasar atau value konsumen dengan kemampuan spesifik yang dimiliki produsen atau penyuplai.

Kemampuan inti setiap organisasi itu berbeda, ia adalah bagian dari kepribadian organisasi. Tetapi setiap organisasi - bukan hanya organisasi bisnis saja - memerlukan satu kemampuan inti: inovasi. Setiap organisasi juga memerlukan suatu cara untuk mencatat dan memberi penghargaan untuk unjuk-kerja yang inovatif.

4. Information alokasi sumber-sumber. Informasi ini diperlukan untuk mengelola bisnis yang sekarang agar mampu menciptakan kemakmuran melalui pemanfaatan sumber-sumber yang langka: kapital dan karyawan yang handal. Informasi apa saja yang dimiliki manajemen, selama masih berkenaan dengan kedua sumber inti tersebut, perlu dikonversikan ke dalam tindakan. Kedua informasi ini akan menentukan apakah perusahaan akan sukses atau tidak.

Pertanyaan yang muncul kemudian adalah "Apakah harga murah (sebagai hasil dari pengurangan biaya pada setiap tahapan proses jasa) untuk jasa yang berkualitas tinggi benar-benar mencerminkan value konsumen yang paling tinggi? Bukankah masih ada kemungkinan bahwa meskipun kualitas dari produk (jasa) yang ditawarkan sangat tinggi, namun ternyata jasa yang ditawarkan itu sudah tidak lagi diminati konsumen? Pertanyaan yang kedua ini harus diajukan, sebab para produsen mungkin menawarkan sesuatu yang 
mereka anggap berkualitas, akan tetapi menurut konsumen kata "berkualitas" itu berarti pengoperasian (mesin atau sistem, pen.) yang rumit dan membingungkan. Secara singkat dapat dikatakan bahwa meskipun goal nya bagus (untuk memuaskan konsumen), akan tetapi dalam pelaksanaannya, produsen dapat tergelincir sehingga menawarkan sesuatu yang, pada akhirnya, membuat konsumen merasa terasing (alienated) sebab pada kenyataannya konsumen sebenarnya tidak menginginkan perbaikan kualitas (lacobucci, 1996).

Kualitas yang lebih baik dan biaya yang rendah merupakan dua senjata persaingan yang mematikan. Akan tetapi, dua senjata persaingan ini belum mencukupi untuk menghadapai persaingan di masa depan. Tapscot (1996) mengatakan bahwa muatan pengetahuan di dalam produk-produk yang sangat menantikan perubahan merupakan cara baru yang semakin populer untuk meningkatkan value di mata konsumen.tentang dalam ekonomi baru (masa datang), penambahan ide-ide terhadap produk dan memeras ide-ide baru untuk diletakkan pada produk-produk baru akan sangat mewarnai produkproduk masa datang. Apakah masyarakat berperan sebagai konsumen atau produses, penambahan ide-ide baru akan menjadi sangat penting bagi penciptaan kemakmuran pada ekonomi baru. Mari kita ambil Pizza sebagai contoh. Pengoperasian restoran Pizza Hut Itu memerlukan teknologi rendah. Oleh karena itu, hingga sekarang ini sudah begltu banyak restoran beroperasi ini beroperasi di Indonesia, dimana para konsumen bisa memesan Pizza dengan spesifikasi tertentu dan toppings yang spesifik menurut selera konsumen sendiri. Kemudian pemesanan bisa dilakukan melalui telepon (computer network?), dan meminta restoran untuk mengantarnya ke alamat yang ditentukan konsumen beberapa menit setelah pemesanan dilakukan. Ide-ide konsumen, latar belakang budayanya, pengetahuannya, dan selera konsumen tentang toppings menjadi bagian tidak terpisahkan dari Pizza yang dipesan konsumen. Pemesanan dan/atau pemenuhan pesanan topping menuntut pengetahuan yang luas (harus senantiasa ditingkatkan) tentang isi atau ramuannya dan lebih mass-customized bukannya mass produced agar dapat memenuhi kebutuhan para konsumen individual. Jika sudah demikian, maka gap antara konsumen dan produsen dapat dipersempit. Konsep ini dilaksanakan dan didukung oleh operasi yang efisien yang mampu menurunkan sembarang biaya pada setiap tahapan proses penyajian Pizza.

Namun demikian, konsep penurunan biaya untuk jasa perawatan tidak bisa dengan mudah dilaksanakan. Jasa ini menghadapi resistensi yang cukup kuat berkenaan dengan alternatif biaya yang lebih murah. Pada waktu yang bersamaan, organisasi perawatan kesehatan benar-benar perlu membuka pintunya lebar-lebar untuk menyambut desakan pasar yang semakin menguat. Para profesional perawatan kesehatan sering menggoyangkan bahunya manakala mendengar ungkapan "kekuatan pasar (market force)." Ungkapan itu sebenarnya tidak dimaksudkan untuk membicarakan tentang kebebasan perusahaan asuransi yang mengelola sampai ke hal-hal kecil (micromanage) sedemikian rupa sehingga praktek perawatan kesehatan yang dilakukan para dokter terhadap 
pasien mendatangkan keuntungan2, akan tetapi lebih dimaksudkan sebagai pembicaraan tentang keterbukaan terhadap perubahan teknologi (disruptive technologies) dan model bisnis yang mungkin mengancam status quo namun pada akhirnya mampu meningkatkan kualitas perawatan kesehatan untuk setiap orang (Christensen et. al., 2000).

Pada industri-industri lainnya, para pemain yang dominan memfokuskan upaya mereka pada perbaikan barang dan jasa mereka kepada titik dimana rata-rata konsumen bahkan belum mengetahui apa yang akan mereka gunakan (bayangkan tentang bagaimana sikap konsumen dalam menghadapi komputer yang demikian canggihnya atau overengineered computers). Para produsen tidak mampu menemukan produk (offering) yang lebih sederhana, lebih nyaman, dan murah yang, mestinya, sejak awal sudah di-design untuk melayani segmen pasar terrendah. Seiring dengan berjalannya waktu, produk yang lebih sederhana akan menjadi lebih bisa diterima - jauh lebih baik sehingga mampu memenuhi kebutuhan mayoritas penggunanya.

Perubahan inovatif dapat menjadi sarana untuk memproses produkproduk yang lebih murah, lebih sederhana, dan lebih nyaman atau pelayanan yang sejak dari awal sudah mampu memenuhi kebutuhan konsumen yang kurang permintaannya (less-demanding) sekalipun. Sebut saja ini sebagai inovasi disruptif. Pada sisi lain, perbaikan pada suatu industri menciptakan seperti yang diperkenalkannya sebagai produk yang labih canggih untuk melayani konsumen yang juga lebih canggih untuk pasar yang permintaannya bagus (sustaining innovation). Inovasi disruptif sangat diperlukan untuk menangani pasien yang memiliki persoalan yang kompleks, problem interaktif seperti para orang tua yang menderita kelumpuhan akibat komplikasi jangka lama antara diabetes, hypertensi, dan penyakit jantung. Contoh ini menggambarkan situasisituasi dimana sejumlah sistem dari tubuh terlibat, sehingga sebab dan akibatnya sulit teridentifikasi. Dengan analogi ini, ktapun menjadi mafhum bahwa persoalan seputar SI, dalam bidang yang lebih luas, terkadang juga menghadapi situasi semacam ini.

\section{SISTEM INFORMASI DAN PROBLEM-PROBLEM REKAYASA}

Alat utama dalam persaingan selama dekade terakhir adalah rekayasa proses bisnis (RPB). RPB adalah pendekatan yang lebih komprehensif yang secara urgen dibutuhkan untuk menangani tantangan situasi baru. Apa yang menjadi persoalan pada setiap kasus adalah bahwa teknologi-teknologi baru mampu mengubah bukan hanya proses bisnis, akan tetapi juga cara barang atau jasa diciptakan dan dipasarkan, struktur dan tujuan perusahaan, dinamika persaingan, dan perilaku aktual perusahaan.

\footnotetext{
2 Konteks jasa perawatan kesehatan dalam uraian di atas sangat Amerika, dimana hampir setiap orang mengasuransikan kesehatannya. Dengan cara ini perawatan si sakit tidak direcoki dengan urusan "siapa yang akan menanggung biaya perawatan pasien ini?", seperti yang ulang kali terjadi di rumah sakit di Indonesia. Asuransi kesehatan di Amerika sangat memudahkan prosedur (penanggungan biaya) perawatan kesehatan si pasien.
} 
Akan tetapi menurut Tapscot (1996) ada empat persoalan menyangkut praktek perekayasaan bisnis:

1. Tekanan untuk menurunkan biaya. Penurunan biaya merupakan fokus (tujuan) bagi kebanyakan bisnis di masa lalu, dan perekayasaan bisnis sesuai dengan tujuan itu. Karena itu downsizing, rightsizing, smartsizing, streamlining, working out, and perekayasaan telah menjadi euphemisme untuk pemangkasan biaya.

Akan tetapi, begitu ekonomi baru mulai tumbuh, perusahaanperusahaan pada kebanyakan sektor butuh fokus kepada pertumbuhan dan penciptaan nilai-tambah, bukan hanya sekedar penurunan biaya. Pengawasan biaya akan selamanya penting dan pada sejumlah sektor menjadi kunci untuk keberhasilan kompetitif. Namun, meski pada bisnisbisnis yang sangat sensitif seperti eceran, mereka perlu mengubah paradigma bisnisnya - misalnya pemasaran melalui media elektronik untuk menyampaikan barang dan bukannya membangun infrastruktur. RPB saja belum mencukupi dan dalam beberapa kasus merupakan penyimpangan dari cara berpikir terkotak-kkotak. Apakah perekayasaan itu sudah terrencana dengan baik atau tidak, upaya ini tetap memiliki bahaya bagi perusahaan yang memasuki anorexia perusahaan baru. Istilah ini digunakan oleh konsultan manajemen terkenal Gary Hamel, dimana untuk pengawasan biaya dilakukan melalui pengurangan pangsa pasar, perolehan, profit, daya saing jangka panjang, dan viabilitas secara permanen.

2. RPB berfokus kepada proses-proses biusnis. Di dalam suatu bisnis ada lebih dari satu set proses, karena itu perbaikan proses merupakan upaya yang tidak mencukupi untuk merespon tantangan-tantangan dalam ekonomi baru. Proyek-proyek RPB biasanya kehilangan kesempatan untuk menjadi lebih dari sekedar penyederhanaan pekerjaan (streamlining of work) hingga ke transformasi obyektif bisnis dan efektivitas. titik pijakan transfoamsi harus bukan pada proses bisnis, tetapi pada model bisnis - yang merupakan abstraksi tingkat tinggi tentang cara bagaimana bisnis merespon terhadap dan menciptakan permintaan sebagai hasil dari perubahan model bisnis mereka, dan teknologi memungkinkan dilakukannya perubahan seperti ini.

Perekayasaan biasanya berfokus pada dan menyebabkan terciptanya proses bisnis yang terstruktur. Namun demikian, dalam ekonomi baru sebagaian besar dari upaya tersebut merupakan kerja pikir berdasarkan tim, perubahan jaringan manusia, jenis pekerjaan baru, komunikasi, kolaborasi ad hoc, dan brainstorming untuk kepentingan inovasi. Ponder, sebagaimana dikutip oleh Tapscot (1996) menyatakan bahwa perekayasaan tidak mampu mentransformasi suatu bisnis. Rekayasa berorientasi pasar, bukannya berorientasi ke proses.

3. Keharusan sumber daya manusia. Dalam berbagai situasi, proyek-proyek RPB telah saham paham terhadap peran sumber daya manusia. Para pekerja sering tidak menerima proyek-proyek besar yang tujuannya memangkas biaya, karena pekerja yang kurang motivasi melakukan 
rekayasa proses bisnis. Fenomena ini sejalan dengan apa yang dikatakan oleh Paul Strassman sebagai "kejahatan rekayasa" dan perusahaanpun sampai pada suatu situasi yang menakutkan. Jadi menemukan sisi gelap dari proses rekayasa adalah perkara mudah.

Namun demikian, banyak upaya rekayasa secara keliru diasumsikan bahwa beberapa pimpinan senior atau steering committee dapat, dalam cara top-down, memahami proses bisnis dan juga kesempatan perubahan dan menjual visi ke seluruh organisasi. Pendekatan demikian bertentangan dengan pemikiran modern dan praktek tentang penciptaan learning organization, shared vision, dan team leadership.

Rekayasa juga telah kehilangan implikasi TI dalam pengertian yang lebih luas - yang memungkinkan transformasi bisnis atas aspek lain yang terlihat nyata tentang pekerjaan manusia dan kehidupan sosialnya. Isu-isu besar yang harus ditangani - sejak dari kualitas hidup - pekerjaan, pelatihan ulang, dan pembelajaran sepanjang hidup pada ekonomi baru, perubahan dunia kerja dan korier sebagai yang kita ketahui, bahaya dari gap antara yang kaya dengan yang tidak kaya, semua jalan ke arah perubahan fundamental dalam dunia kerja pemerintah, proses demokratisasi, dan demokrasi itu sendiri.

4. Pandangan paradigma lama tentang teknologi. Banyak rekayasa terdahulu menganggap TI penting bagi proses bisnis baru. Namun demikian, lebih dari sekedar Perubahan Paradigma, tidak ada satupun yang benar-benar menerangkan bagaimana paradigma lama dalam teknologi kurang disaranai untuk kepentingan perusahaan baru. Ebagai hasilnya, banyak perusahaan telah melemparkan teknologi paradigma lamanya sehingga menjadi persoalan pada paradigma baru rekayasa. Untuk menghasilkan organisasi yang berunjukerja tinggi, terintegrasi, terhubungkan dengan lainnya, terbuka, dan berorientasi melayani konsumen, perusahaan-perusahaan memerlukan teknologi baru yang berunjuk-kerja tinggi, terintegrasi, terhubungkan dengan lainnya, terbuka, dan berorientasi kepada pelayanan klien. Model lama perhitungan - unjuk-kerja rendah (mainframe tradisional atau minicomputer) tidak terintegrasi (berdasarkan pada islands of computing), host-based (dan bukannya networked), mencukupi (tidak menganut standar tertentu), komando dan kontrol (tidak seperti client-server) - adalah antitesis dari perusahaan baru dimasa datang.

\section{PENUTUP}

Untuk mengatasi sejumlah persoalan seperti yang digambarkan di atas, yang mungkin dihadapi oleh perusahaan yang harus melakukan rekayasa organisasi dan prosesnya, Drucker (1995), Druker sekali lagi memberi saran yang sangat bagus agar para manajer secara lebih jelas memahami lebih dahulu dan membedakan antara konsep dan alat. Sarannya ini sangat penting sebab ada sejumlah konsep yang mendasari penggunaan alat-alat tersebut di atas. Sejumlah alat telah digunakan sekian lama, tetapi jarang, bila pernah, difokuskan pada tugas pengelolaan bisnis dengan baik. Sejumlah diantaranya telah diperbaiki 
(reengineered); sebab untuk situasi sekarang mereka tidak lagi sesuai. Padahal sejumlah alat itu menjanjikan kepentingan yang besar di masat datang.

Konsep-konsep dan alat-alat saling tergantung secara mutualistik dan interaktif. Bila satu berubah, maka yang lain pun berubah. Itulah yang sekarang terjadi pada konsep yang kita sebut saja bisnis dan untuk alat kita sebut saja informasi. Alat baru ini memungkinkan kita melihat bisnis secara berbeda, yaitu:

1. Sebagai generator dari sumber-sumber, yaitu sebagai organisasi-organisasi yang bisa merubah biaya bisnis menjadi perolehan (yields)

2. Sebagai penghubung dalam rantai ekonomi, yang mana para manajer perlu memahami secara keseluruhan dalam rangka mengelola biayabiaya mereka

3. Sebagai organ-organ sosial mereka dalam menciptakan kemakmuran dan

4. Sebagai, baik makhluk maupun pencipta lingkungan material, area yang berada di luar organisasi di dalam mana kesempatan-kesempatan dan hasil-hasil muncul maupun drimana ancaman-ancaman bagi keberhasilan dan kelangsungan hidup setiap bisnis berasal.

\section{DAFTAR PUSTAKA}

BTIner, Mary Jo, (1996). A Computerized System Forces Customers to Become, Essentially, Part-time Employees of the Company. (tulisan ini dibuatnya sebagai respon terhadap studi kasus yang diajukan oleh Dawn lacobucci dengan judul: The Quality Improvement Customers Didn't Want). HBR. January - February, 1996.

Christensen, Clayton M.; Bohmer, Richard; Kenagy, John. (2000). Will Disruptive Innovations Cure Health Care?. Harvard Business Review (HBR). September-October.

Drucker, Peter F. (1995). The Information Executives Really Need. HBR, JanuaryFebruary. Pp. 54-62.

lacobucci, Dawn. (1996). The Quality Improvement Customers Didn't Want (Case Study). HBR. January - February. Pp.20 - 36.

Jones, Thomas O., (1996). Should Quality Care Install the New System? (Tulisan dengan judul tersebut merupakan tanggapan untuk studi kasus yang diajukan oleh Dawn lacobucci dengan judul: The Quality Improvement Customers Didn't Want). HBR, January - February. Pp. 25-26.

Kotter, John P. (1995). Leading Change: Why Transformation Effort Fail. HBR. March-April. Pp. 59-67.

Lovelock, Christopher. (1994). Product Plus, How Product + Service = CompetTlive Advantage. McGraw-Hill International Edition. New York.

Martin, E. Wainright; Carol V. Brown; Daniel W. DeHayes; Jeffrey A. Hoffer; dan Wlliam C. Perkins, (1999). Managing Information Technology. $3^{\text {rd }}$ Edition (International Edition), Prentice Hall, Inc. New Jersey.

Quinn, Robert E. (1996). Deep Change, Discovery the Leader Within. Jossey-Bass Publishers. San Fransisco. 
Reichheld, Frederick F. (1996). Learning from Customer Defections. HBR. MarchApril. Pp. 56-69.

Robbin, Stephen P. (1994). Essence of Organizational Behavior. Prentice-Hall, Fourth Edition. International Edition. New Jersey.

Robbins, Stephen P. (1997). Managing Today. Prentice-Hall International Inc. International Edition. New Jersey.

Schermerhorn, John R. Jr., (1996). Management, $5^{\text {th }}$ EdTlion, John Wiley \& Sons, Inc., New York.

Setianingsih, Sunarti. (1998). Keberhasilan Pengembangan Sistem Informasi dan Faktor-faktor yng Mempengaruhinya. Kajian Bisnis. No. 13. Januari April. Hal. 83-91.

Tapscott, Don. (1995). Digital Economy, Promise and Peril in the Age of Networked Intelligence. McGraw-Hill. USA. 